\title{
Geniposide promotes beta-cell regeneration and survival through regulating $\beta$-catenin/TCF7L2 pathway
}

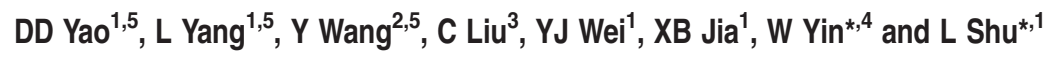

T-cell factor 7-like 2 (TCF7L2) is an important transcription factor of Wnt/ $\beta$-catenin signaling, which has critical roles in $\beta$-cell survival and regeneration. In preliminary screening assay, we found geniposide, a naturally occurring compound, was able to increase TCF7L2 mRNA level in Min6 cells. Here we aimed to investigate the role of geniposide in $\beta$-cell and underlying mechanism involved. Geniposide was found to promote $\beta$-cell survival by increasing $\beta$-cell proliferation and decreasing $\beta$-cell apoptosis in cultured mouse islets after challenge with diabetic stimuli. Geniposide protected $\beta$-cell through activating Wnt signaling, enhanced expressions of TCF7L2 and GLP-1R, activated AKT, inhibited GSK3 $\beta$ activity, and promoted $\beta$-catenin nuclear translocation. The protective effect of geniposide was remarkably suppressed by siRNAs against $\beta$-catenin, or by ICG001 ( $\beta$-catenin/TCF-mediated transcription inhibitor). Moreover, geniposide promoted $\beta$-cell regeneration in vivo to normalize blood glucose in high-fat diet and $\mathrm{db} / \mathrm{db}$ mice. Increased $\beta$-cell proliferation was observed in pancreatic sections of geniposide-treated diabetic mice. Most importantly, geniposide triggered small islet-like cell clusters formation as a result of $\beta$-cell neogenesis from ductal epithelium, which was well correlated with the increase in TCF7L2 expression. In exocrine cells isolated from mouse pancreas, geniposide could induce duct cell differentiation through upregulating TCF7L2 expression and activating JAK2/STAT3 pathway. Taken together, we identified a novel role of geniposide in promoting $\beta$-cell survival and regeneration by mechanisms involving the activation of $\beta$-catenin/TCF7L2 signaling. Our finding highlights the potential value of geniposide as a possible treatment for type 2 diabetes.

Cell Death and Disease (2015) 6, e1746; doi:10.1038/cddis.2015.107; published online 7 May 2015

Diabetes is characterized by $\beta$-cell loss and dysfunction. ${ }^{1,2}$ One therapeutic strategy for diabetes is to prevent $\beta$-cell failure and to promote new $\beta$-cell formation. Lineage-tracing experiments have shown that new $\beta$-cells can arise from proliferation of preexisting $\beta$-cells. ${ }^{3}$ An alternative source of $\beta$-cells has been explored that facultative progenitors can be found in regenerating pancreatic ducts. ${ }^{4}$ Pancreatic duct cells are considered a potential source of $\beta$-cell regeneration.

In recent years, the role of $\mathrm{Wnt} / \beta$-catenin pathway in type 2 diabetes mellitus (T2DM) has been increasing appreciated. ${ }^{5,6}$ $\mathrm{Wnt} / \beta$-catenin signaling is a key modulator for $\beta$-cell insulin secretion, ${ }^{7} \quad \beta$-cell neonatal growth, and regeneration. ${ }^{8}$ As a major transcription factor of Wnt signaling, T-cell factor 7-like 2 (TCF7L2) was shown to mediate its effects through glucagon-like peptide 1 receptor (GLP-1R) signals in our previous publications. TCF7L2 overexpression could enhance GLP-1R expression and activate downstream pathway AKT consequently, ${ }^{9}$ promote $\beta$-cell regeneration in vivo $^{10}$ by triggering the conversion from ductal epithelial cell to $\beta$-cell, and protect $\beta$-cell from glucose and pro-inflammatory cytokine-mediated toxicity. ${ }^{11}$ Reports from other groups also confirmed that TCF7L2 was able to improve $\beta$-cell survival, function, and regeneration..$^{8,12-14}$ Also, TCF7L2/ $\beta$-catenin itself promotes synthesis of GLP-1 in intestinal L-cells. ${ }^{15}$

Given the important role of TCF7L2 in $\beta$-cell survival, we conducted a small-scale natural-compound-screening assay in Min6 cells, with an aim to identify small molecules that can increase TCF7L2 mRNA level. Geniposide, a natural dietary pigment isolated from the gardenia fruits, has emerged as a promising candidate because it significantly increased TCF7L2 mRNA level in cells treated with high glucose.

Gardenia fruits have been used as a traditional herbal medicine that possess anti-inflammatory, ${ }^{16}$ antioxidative, ${ }^{17}$ and hypoglycemic properties. ${ }^{18}$ One study showed geniposide decreased the expression of glucose-6-phosphatase in a diabetic mouse model induced by 3-week high-fat diet (HFD) feeding combined with streptozotocin injection. ${ }^{19}$ Of note, it is not an appropriate animal model for T2DM study. In recent studies, geniposide was shown to stimulate insulin secretion in INS-1 cells in different glucose concentrations by activating

\footnotetext{
${ }^{1}$ Key Laboratory of New Drug Delivery System of Chinese Materia Medica, Jiangsu Province Academy of Chinese Medicine, Nanjing, China; ${ }^{2}$ Jiangsu Key Laboratory of Xenotransplantation, Nanjing Medical University, Nanjing, China; ${ }^{3}$ Department of Endocrinology, Jiangsu Province Hospital on Integration of Chinese and Western Medicine, Nanjing University of Chinese Medicine, Nanjing, China and ${ }^{4}$ State Key Laboratory of Pharmaceutical Biotechnology, School of Life Sciences, Nanjing University, Nanjing, China

*Corresponding author: L Shu, Key Laboratory of New Drug Delivery System of Chinese Materia Medica, Jiangsu Province Academy of Chinese Medicine, 100 Shizi Road, Nanjing 210028, China. Tel: +86 25 85608672; Fax: +86 25 85637809; E-mail: shuluan2006@ hotmail.com

or W Yin, State Key Laboratory Pharmaceutical Biotechnology, School of Life Sciences, Nanjing University, Nanjing 210093, China. Tel: +86 25 66099006; Fax: +86 25 89681347; E-mail: wyin2003@163.com

${ }^{5}$ These authors contributed equally to this work.

Abbreviations: GLP-1R, glucagon-like peptide 1 receptor; GSIS, glucose-stimulated insulin secretion; Glut2, glucose transporter 2; HFD, high-fat diet; ICCs, small isletlike cell clusters; IPGTT, intraperitoneal glucose tolerance test; MafA, musculoaponeurotic fibrosarcoma oncogene family A; ND, normal diet; Ngn3, neurogenin 3; PDX-1, pancreatic and duodenal homeobox 1; TCF7L2, T-cell factor 7-like 2; T2DM, type 2 diabetes; WT, wild type

Received 29.8.14; revised 17.3.15; accepted 18.3.15; Edited by E Baehrecke
} 
GLP-1R. ${ }^{20}$ In addition, geniposide could counteract lipotoxicity-induced INS-1 cell apoptosis, through GLP-1R signaling. ${ }^{21}$ However, whether geniposide can modulate $\beta$-cell regeneration and whether the possible effect of geniposide is mediated by TCF7L2/ $\beta$-catenin signaling remain largely unknown. To answer these questions, we initiated this study.

In the present study, we evaluated the effects of geniposide on $\beta$-cell survival and regeneration and investigated the underlying mechanisms as well. Isolated mouse islets and Min6 cells were used to explore effects of geniposide on $\beta$-cell survival in vitro. HFD-induced diabetic mice and $\mathrm{db} / \mathrm{db}$ mice were used to investigate $\beta$-cell regeneration in vivo.

\section{Results}

Geniposide protected islet $\beta$-cells against glucose and pro-inflammatory cytokine-mediated toxicity by upregulating TCF7L2 expression. In the present study, Ki67 immunostaining was used to examine cell proliferation, and TUNEL staining was used to assess apoptosis. The results, shown in Figures $1 \mathrm{a}$ and $\mathrm{b}$, demonstrated that treatment with high-concentration glucose $(33.3 \mathrm{mM})$ or a mixture of cytokines (IL- $1 \beta$ plus IFN- $\gamma$ (ILIF)) reduced $\beta$-cell proliferation and induced $\beta$-cell apoptosis compared with the levels observed in $11.1 \mathrm{mM}$ glucose-treated cells. Notably, islets treated with geniposide were protected against these deleterious effects. In islets treated with $33.3 \mathrm{mM}$ glucose, geniposide increased $\beta$-cell proliferation (2.8-fold) and decreased apoptosis (1.84-fold) compared with that observed in DMSO-treated cells. Similarly, in ILIF-treated islets, geniposide increased $\beta$-cell proliferation 3.4-fold and decreased apoptosis up to 1.88-fold compared with that observed in DMSO-treated cells (Figure 1b). Meanwhile, the effect of geniposide on islet $\beta$-cell function was evaluated by GSIS (glucose-stimulated insulin secretion) assay (Supplementary Figure S3). The insulin secretion of islets was not significantly impacted by geniposide.

To confirm the preliminary result that geniposide can upregulate TCF7L2 mRNA levels in Min6 cells, cultured mouse islets were exposed to $33.3 \mathrm{mM}$ glucose as a diabetic stimulus. As shown in Figure 1c, the mRNA levels of TCF7L2, pancreatic and duodenal homeobox 1 (PDX-1), and insulin were remarkably reduced in islets exposed to $33.3 \mathrm{mM}$ glucose compared with that in $11.1 \mathrm{mM}$ glucose-treated cells. In the adult pancreas, PDX-1 is a transcription factor that regulates the expression of $\beta$-cell-specific genes including insulin and Glut2, also multiple aspects of $\beta$-cell function and survival. Here we observed that the mRNA levels of $P D X-1$ and insulin were increased by geniposide 4.2-fold and 1.95fold, respectively, compared with their levels in DMSO-treated islets. Meanwhile, TCF7L2 mRNA levels in islets were increased 4.1 -fold by geniposide treatment. Cyclin D1, a target gene of the $\beta$-catenin/TCF transcription complex, was also increased 3.7-fold by geniposide treatment than the levels in control islets.

$\mathrm{IL}-1 \beta$ is a pro-inflammatory cytokine known to cause $\beta$-cell failure and destruction. ${ }^{22} A$ previous study showed that in human islets, glucose-induced $\beta$-cell apoptosis and dysfunction are partly accounted for by the IL- $1 \beta$ secreted from the $\beta$-cells themselves. ${ }^{23}$ Here we showed that exposure to $33.3 \mathrm{mM}$ glucose increased IL-1 $\beta$ mRNA levels in cultured islets, and this increase was significantly suppressed by geniposide treatment (Figure 1c).

Simultaneously, TCF7L2 expression in treated islets was measured by western blotting (Figure 1d). We previously showed that exposure to high glucose or a cytokine mixture decreased TCF7L2 expression in islets. ${ }^{11}$ Here we showed that geniposide treatment significantly restored the impaired TCF7L2 expression in high glucose- or cytokine mixturetreated islets. Moreover, the decrease in AKT phosphorylation and the increase in caspase-3 cleavage induced by high glucose or the cytokine mixture were also largely reversed by geniposide treatment. In $11.1 \mathrm{mM}$ glucose-cultured islets, TCF7L2 expression and p-AKT levels also appeared to be enhanced by geniposide treatment; however, the caspase-3 cleavage was not significantly affected.

Geniposide activated $\beta$-catenin/TCF7L2 signaling to prevent glucose and pro-inflammatory cytokinemediated toxicity. In general, TCF7L2 exerts its biological activity through $\beta$-catenin/TCF7L2-mediated transcription. In this study, the effect of geniposide on $\beta$-catenin translocation was first examined in Min6 cells. Consistent with the results from islets, in Min6 cells, the diabetic stimuli decreased p-AKT and p-GSK3 $\beta$ levels. However, geniposide treatment increased the $p-A K T$ and $p-G S K 3 \beta$ levels, which can promote $\beta$-catenin stabilization and translocation (Figure 2a). The western blot analysis revealed that in Min6 cells under diabetic stimuli, $\beta$-catenin predominantly accumulated in the cytoplasmic fraction (Figure 2b). However, after geniposide treatment, $\beta$-catenin translocated into the nucleus, and the nuclear/cytosolic ratio of $\beta$-catenin was significantly elevated than that observed in DMSO-treated cells.

To further investigate the role of $\beta$-catenin/TCF7L2 and GLP-1R in geniposide's effect, islets were treated with exendin (9-39), an antagonist of GLP-1R, and ICG001, a transcriptional inhibitor of $\beta$-catenin/TCF. In $33.3 \mathrm{mM}$ glucose-exposed cells, the regulatory effects of geniposide on p-AKT, p-GSK3 $\beta$, and caspase-3 cleavage were significantly suppressed by ICG001, but not significantly prevented by exendin (9-39) (Figure 2c). The classical GLP-1R signaling in pancreatic $\beta$-cells mediates PI3K/AKT activation and PKA activation by increasing cAMP levels. ${ }^{24}$ In this study, expression of the PKA catalytic subunit PKA C- $a$ was examined. Again, geniposide restored the decreased PKA C- $a$ expression induced by $33.3 \mathrm{mM}$ glucose exposure, meanwhile, this effect was strongly suppressed by ICG001, but was not affected by exendin (9-39). Downregulation of GLP-1 and GIP receptor expression in hyperglycemia have been reported in our previous studies $^{9}$ as well as other publications. ${ }^{25,26}$ Interestingly, here we observed that geniposide can upregulate GLP-1R expression, which may explain the different effects of ICG001 and exendin (9-39) on the effect of geniposide.

Geniposide protected $\beta$-cell survival from glucosemediated toxicity in a $\beta$-catenin/TCF7L2 signalingdependent manner. Effects of exendin (9-39) and ICG001 on $\beta$-cell turnover were examined in $33.3 \mathrm{mM}$ glucose-treated mouse islets by Ki67 and TUNEL staining assays (Figures 3a 
a

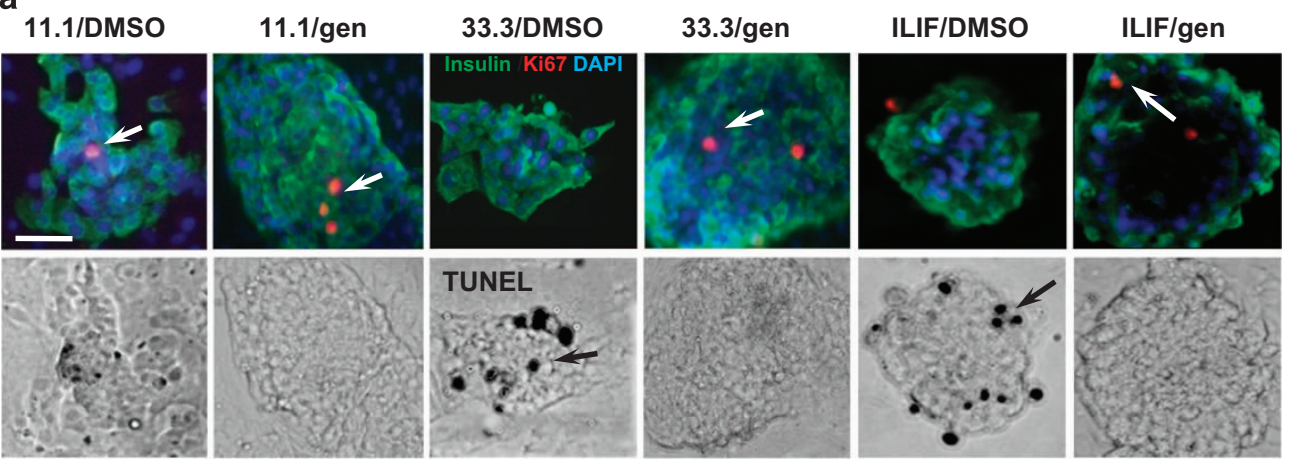

b
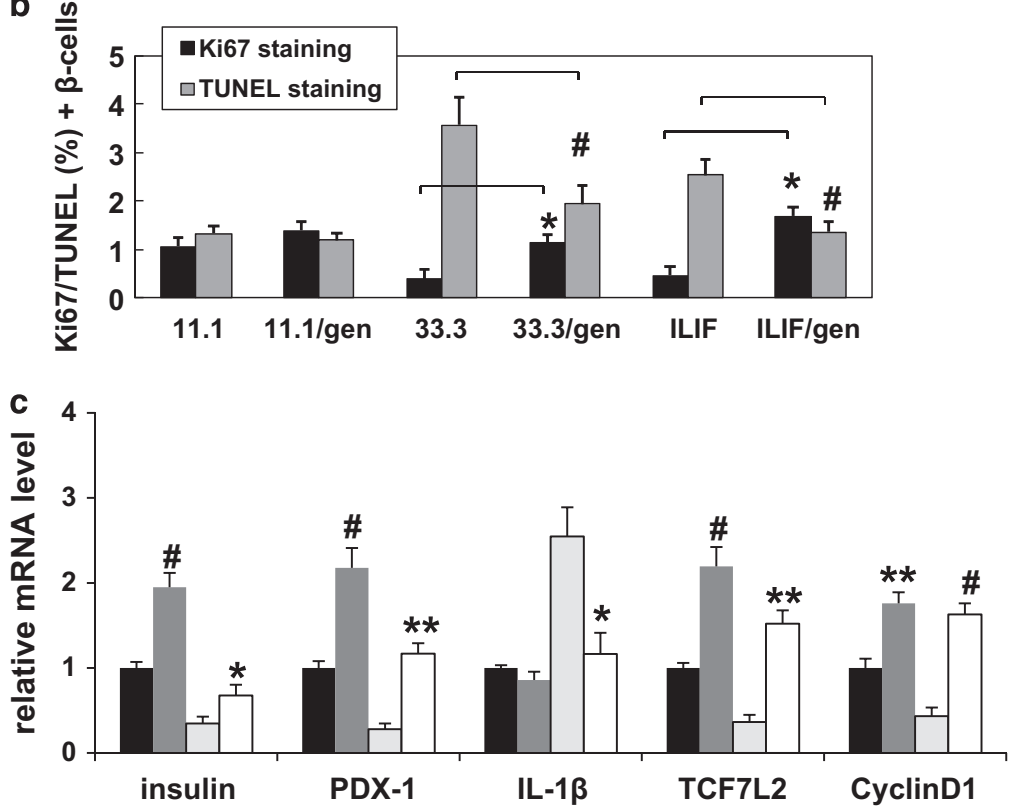

- 11.1/DMSO

11.1/gen

33.3/DMSO

$\square$ 33.3/gen
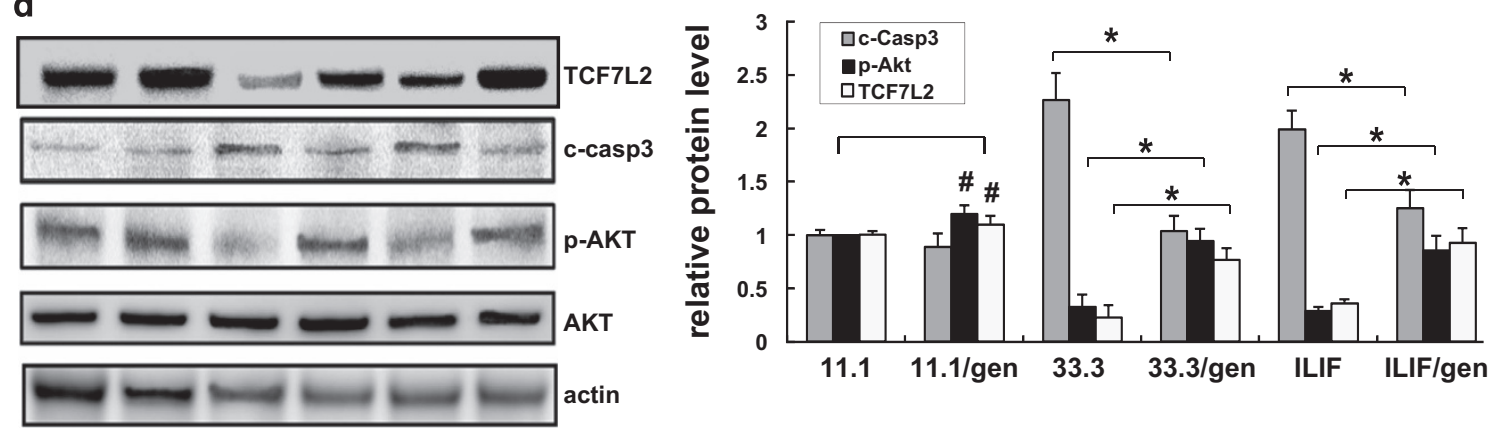

11.1 11.1/gen $33.3 \quad 33.3 / g e n$ ILIF ILIF/gen

Figure 1 Geniposide protected islet $\beta$-cells by upregulating TCF7L2 expression. (a) Isolated mouse islets were exposed to diabetic stimuli (33.3 mM glucose or the mixture of $2 \mathrm{ng} / \mathrm{ml}$ IL-1 $1 \beta$ plus $1000 \mathrm{U} / \mathrm{ml}$ IFN- $\gamma($ ILIF)) with geniposide $(20 \mu \mathrm{M})$ or DMSO as control for 3 days. Proliferation was measured by the Ki67 staining (in red, indicated by white arrows), and apoptosis by the TUNEL assay stained in black (indicated by black arrows). Islets were triple-stained for insulin in green and counterstained for DAPI in blue. Scale bars, $20 \mu \mathrm{m}$. (b) Results are expressed as means \pm S.E. of the percentage of Ki67-positive or TUNEL-positive $\beta$-cells. ${ }^{*} P<0.05$, geniposide to DMSO (Ki67 staining); ${ }^{\#} P<0.05$, geniposide to DMSO (TUNEL assay). (c) RT-PCR analysis of mRNA isolated from the islets cultured in 11.1 or $33.3 \mathrm{mM}$ glucose with/without geniposide. Results were normalized to tubulin. Data are shown as mean \pm S.E. from three independent experiments. $\left({ }^{\sharp} P<0.05\right.$, geniposide to DMSO in $11.1 \mathrm{mM}$ glucose-treated islets; ${ }^{*} P<0.01,{ }^{* \star} P<0.005$, geniposide to DMSO in $33.3 \mathrm{mM}$ glucose-treated islets). (d) Representative western blots for the diabetic stimuli-treated islets. The densitometric analyses of three independent experiments are shown. ( ${ }^{\#} P<0.05$, geniposide to DMSO in $11.1 \mathrm{mM}$ glucose-treated islets; ${ }^{*} P<0.05$, geniposide to DMSO in $33.3 \mathrm{mM}$ glucose- or ILIF-treated group) 
a

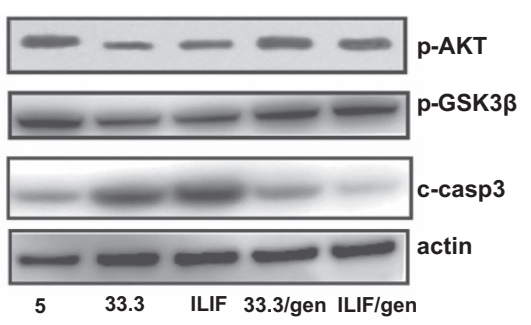

b

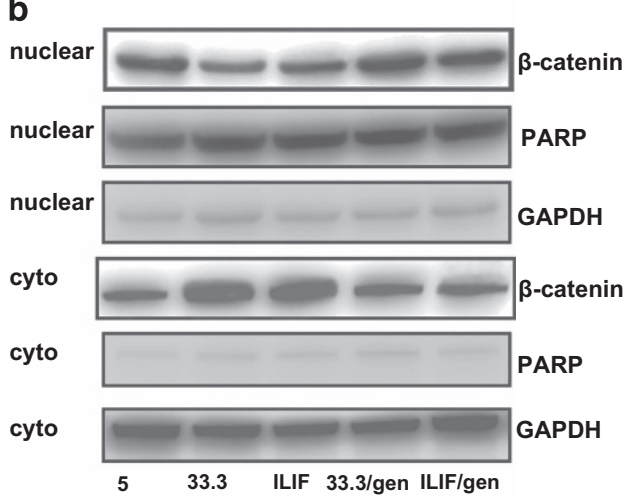

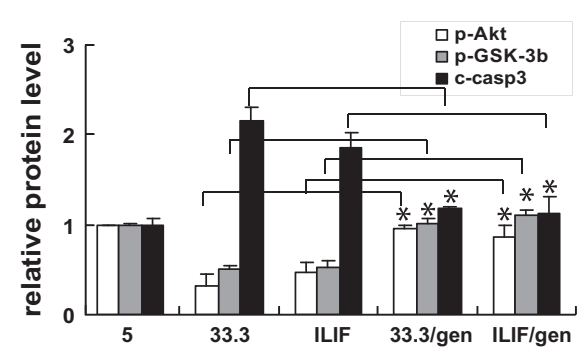

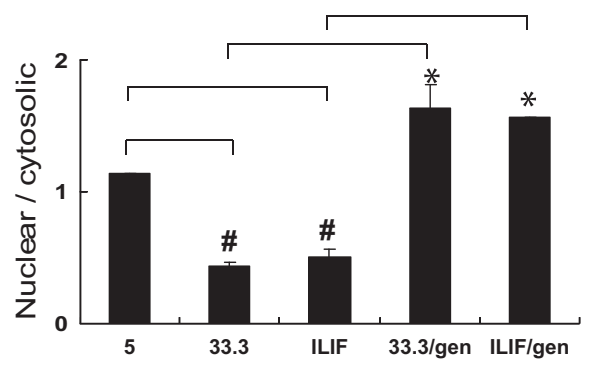

C
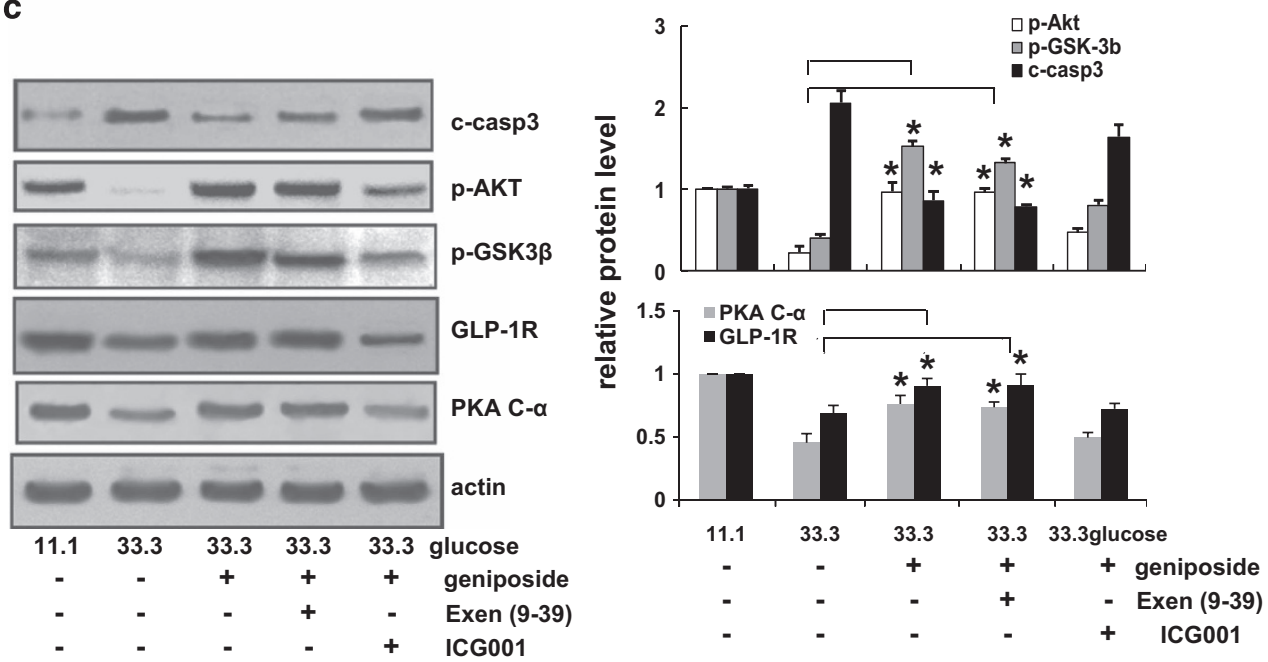

Figure 2 Geniposide activated $\beta$-catenin/TCF7L2 signaling in $\beta$-cell. (a) Representative western blots from the diabetic stimuli-treated Min6 cells. (b) Western blot analysis of the $\beta$-catenin cellular distribution in Min6 cells after treatment with geniposide. The densitometric analyses of three independent experiments are shown. $\left({ }^{\#} P<0.05\right.$ to $5 \mathrm{mM}$ glucose-cultured min6 cells; " $P<0.05$, geniposide to DMSO). (c) Western blot analysis of effects of Exen (9-39) (a GLP-1R antagonist; $200 \mathrm{nM}$ ) or ICG001 (a $\beta$-catenin/TCFmediated transcription inhibitor; $25 \mu \mathrm{M})$ on geniposide-mediated $\beta$-cell protection. Data are shown as mean \pm S.E. from three independent experiments. $\left({ }^{\star} P<0.05\right.$, geniposide to DMSO)

and b). Consistent with results from western blotting assay, the protective effect of geniposide on $\beta$-cell survival was suppressed by treatment with ICG001, largely attenuated by ICG001(Figure 3b, * $P<0.05$, Ki67 staining in 33.3/gen group versus 33.3/gen+ICG001 group, ${ }^{\#} P<0.05$, TUNEL staining in 33.3/gen group versus 33.3/gen+ICG001 group), but remained unaffected in the presence of exendin (9-39) treatment.

To further confirm the involvement of $\beta$-catenin/TCF7L2 in geniposide's effect, $\beta$-catenin expression in isolated mouse islets was reduced by siRNA-mediated gene silencing as described previously. ${ }^{11}$ As shown in Figure $3 c$, the $\beta$-catenin siRNA (si $\beta$-cat) decreased $\beta$-catenin expression by $65.6 \%$ compared with the levels in the scramble siRNA (siScr)transfected islets. We transfected $100 \mathrm{nM}$ si $\beta$-cat to deplete $\beta$-catenin, and then measured the effect of geniposide on $\beta$-cell survival by immunostaining (Figures $3 d$ and e). In the siScr group, $\beta$-cell proliferation in geniposide-treated islets was higher (1.58-fold) than in the DMSO-treated islets. Similar to the results of siTCF7L2 in our previous study, exposure of islets to si $\beta$-cat decreased $\beta$-cell proliferation (1.75-fold) and increased $\beta$-cell apoptosis (3.1-fold; Figure $3 e$ ), and these deleterious effects induced by si $\beta$-cat could not be reversed by geniposide.

These results suggested that the $\beta$-catenin/TCF7L2 signals have a critical role in the geniposide-mediated protective effect 
a

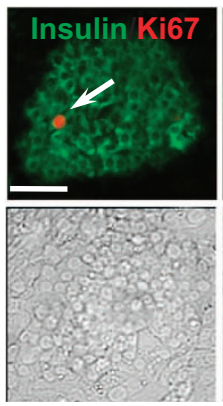

11.1/DMSO

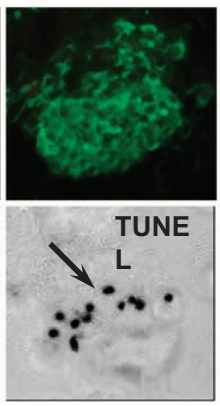

33.3/DMSO
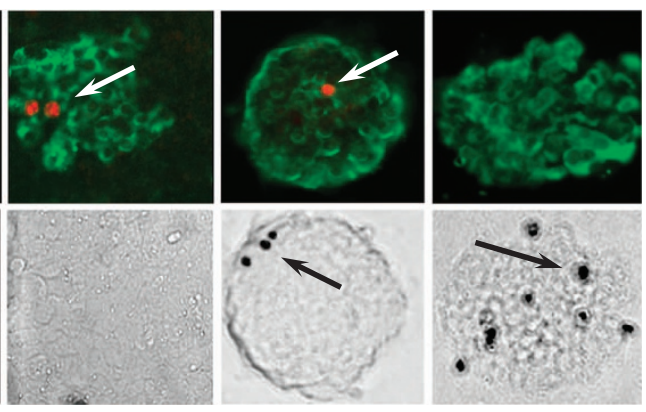

33.3/gen

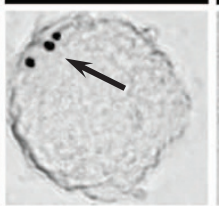

33.3/gen

Exen(9-39)

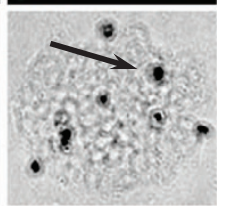

33.3/gen

ICG001

b

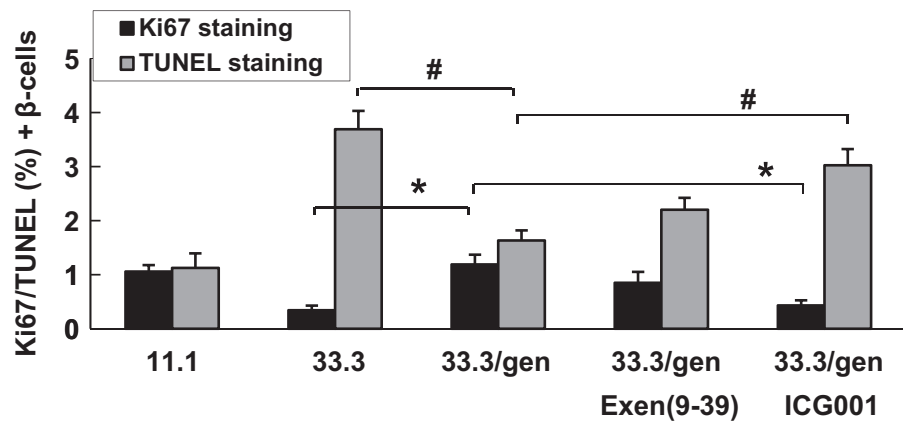

C

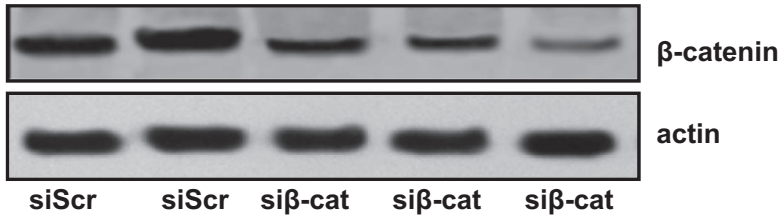

d
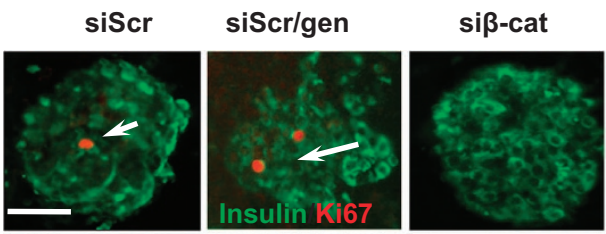

si $\beta$-cat /gen
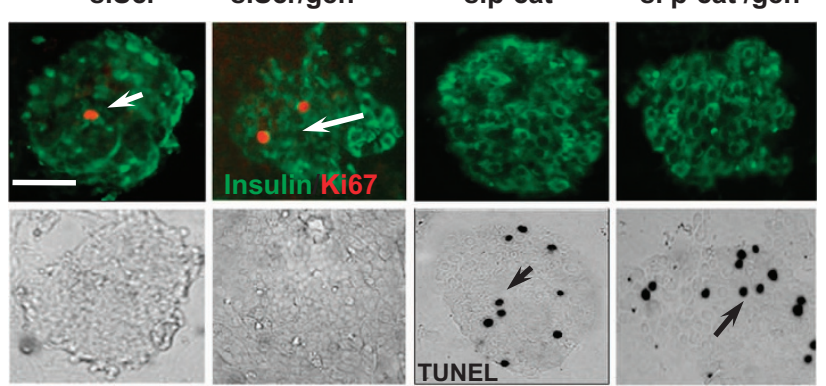

e

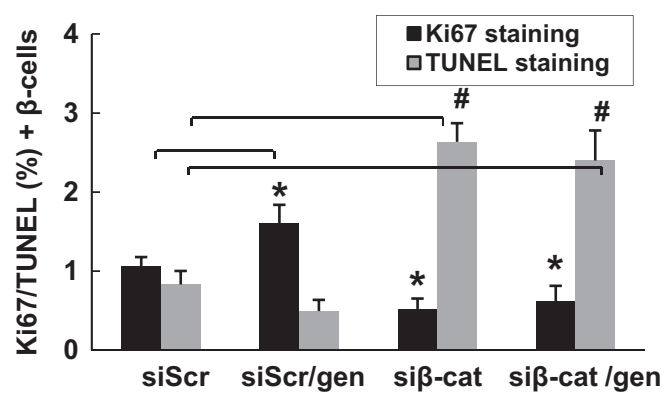

Figure 3 Involvement of $\beta$-catenin/TCF7L2 signaling in the protective effect of geniposide on islets $\beta$-cell survival. (a) Isolated mouse islets were exposed to $33.3 \mathrm{mM}$ glucose with/without geniposide, Exen (9-39), or ICG001 for 3 days. The $\beta$-cell proliferation was measured by the Ki67 staining (in red), and apoptosis by the TUNEL assay stained in black. Islets were co-stained for insulin in green. (b) Results are expressed as means \pm S.E. of the percentage of Ki67-positive or TUNEL-positive $\beta$-cells. ${ }^{*} P<0.05$ (Ki67 staining): ${ }^{\#} P<0.05$ (TUNEL assay), 33.3/gen to 33.3 or 33.3/gen/ICG001 to 33.3/gen. Scale bars, $20 \mu \mathrm{m}$. (c) Representative western blots from islets transfected with siScr or si $\beta$-cat. (d) Isolated mouse islets were treated by siScr or si $\beta$-cat with/without geniposide for 3 days. Proliferation was measured by the Ki67 staining (in red), and apoptosis by the TUNEL assay stained in black. Islets were co-stained for insulin in green. (e) Results are expressed as means \pm S.E. of the percentage of Ki67-positive or TUNEL-positive $\beta$-cells. ${ }^{*} P<0.05$ to DMSO (Ki67 staining); ${ }^{\#} P<0.05$ to DMSO (TUNEL assay). Scale bars, $20 \mu \mathrm{m}$ 
on $\beta$-cell survival. Geniposide might counteract the Exen (9-39) disadvantage through upregulating TCF7L2 and GLP-1R expressions, which lead to activation of GLP-1R downstream pathways.

\section{Geniposide treatment normalized blood glucose levels in $\mathrm{db} / \mathrm{db}$ and HFD mice accompanied by increased $\beta$-cell} mass. The majority of type 2 diabetes rodent animal models are obese, by either genetic or dietary means. Here we used both HFD mice and $\mathrm{db} / \mathrm{db}$ mice to evaluate the antidiabetic effect of geniposide. In our preliminary experiment, we tried three different doses ranging from 100 to $300 \mathrm{mg} / \mathrm{kg}$. All three doses showed significant glucose-lowering effects compared with saline vehicle-treated animals (data not shown); therefore, the dose of $100 \mathrm{mg} / \mathrm{kg}$ was chosen for subsequent experiments.

To assess the ability of geniposide to prevent progression of diabetes, we initially examined its effect in 4-week prediabetic $\mathrm{db} / \mathrm{db}$ mice by oral gavage at a dosage of $100 \mathrm{mg} / \mathrm{kg}$ daily for 56 days. The vehicle $\mathrm{db} / \mathrm{db}$ group developed diabetes at 6 weeks of age, and fasting blood glucose levels continued to increase over time. However, prediabetic $\mathrm{db} / \mathrm{db}$ mice treated with geniposide maintained normal glucose levels until 8 weeks of age and maintained lower glucose levels on subsequent days compared with vehicle-treated $\mathrm{db} / \mathrm{db}$ mice (Figure $4 \mathrm{a}$ ).

To further confirm the in vivo effect of geniposide, another widely used obese T2DM mouse model, 12-week HFDinduced diabetic mice was administered geniposide for 35 days. The 12-week HFD mice showed a marked increase in fasting blood glucose levels compared with the levels in normal-diet (ND) mice (Figure 4b). Geniposide exhibited a hypoglycemic effect on HFD mice after 15 days of treatment compared with vehicle-treated HFD mice, and this effect continued until the end of the experiment.

In parallel, the response to intraperitoneal glucose challenge (IPGTT) was impaired both in $\mathrm{db} / \mathrm{db}$ mice and HFD mice, which resulted in significant increases of glucose levels after glucose injection (Figures $4 \mathrm{c}$ and $\mathrm{d}$ ). Geniposide administration protected the diabetic mice from such increases, and lowered blood glucose levels at all time points during the IPGTT.

Various reagents that increase plasma insulin levels and exert hypoglycemic effects in $\mathrm{db} / \mathrm{db}$ mice have been reported. $^{27-29}$ Here we noticed that geniposide significantly elevated insulin levels in diabetic mice compared with the levels in vehicle-treated diabetic mice (2.2-fold and 1.6-fold higher than corresponding vehicle-treated controls in HFD and $\mathrm{db} / \mathrm{db}$ mice, respectively; Figure $4 \mathrm{e}$ ). Immunostaining for $\beta$-cells showed reduced $\beta$-cell mass (Figure $4 \mathrm{f}$ ) and deteriorated islet morphology (Figure $5 \mathrm{a}$ ) in the vehicle-treated HFD and $\mathrm{db} / \mathrm{db}$ mice. In contrast, the geniposide-treated group exhibited normal islet morphology (Figure 5a) and increased $\beta$-cell mass (a 1.4-fold increase in HFD mice and a 1.8-fold increase in $\mathrm{db} / \mathrm{db}$ mice compared to the $\beta$-cell mass in corresponding vehicle-treated mice; Figure 4f), which can partially account for the increased insulin levels.

In addition, the body weight gain of geniposide-treated $\mathrm{db} /$ $\mathrm{db}$ and HFD mice was lower than that of the corresponding vehicle-treated control mice (Figures $4 a$ and b). However, food intake was not significantly impacted by geniposide treatment (Supplementary Figure S1). Both HFD and $\mathrm{db} / \mathrm{db}$ mice are obese diabetic animal models; therefore, we measured serum total cholesterol and triglyceride content (Supplementary Figure S2). Geniposide treatment significantly decreased total cholesterol levels, but had no remarkable effect on triglyceride levels. The levels of important adipokines, including adiponectin and leptin, were also measured (Supplementary Figure S2). Geniposide treatment reversed the reduction in serum adiponectin levels observed in HFD and $\mathrm{db} / \mathrm{db}$ mice and suppressed the increased leptin levels observed in HFD mice. These data demonstrate the beneficial metabolic effects of geniposide in HFD and $\mathrm{db} / \mathrm{db}$ mice.

Geniposide promoted $\beta$-cell regeneration in vivo. The increase in $\beta$-cell mass induced by geniposide raised the possibility that this compound may stimulate new $\beta$-cell formation. Theoretically, new $\beta$-cells can arise either from differentiation of endocrine progenitor cells or by replication of existing $\beta$-cells. ${ }^{4,30}$ In this study, we first detected $\beta$-cell proliferation by Ki67/insulin immunostaining in pancreatic sections from HFD and $\mathrm{db} / \mathrm{db}$ mice (Figure $5 \mathrm{a}$ ). Positive Ki67 staining of $\beta$-cells was observed in pancreatic sections of ND and wild-type (WT) mice, but was rarely detected in HFD and db/db mice. In contrast, positive Ki67 staining was observed in HFD and $\mathrm{db} / \mathrm{db}$ mice treated with geniposide (3.8-fold and 5.7-fold higher in HFD and $\mathrm{db} / \mathrm{db}$ mice, respectively), which was consistent with results obtained from cultured islets.

Expression of the transcription factor PDX-1 in the pancreatic ductal epithelium, a marker for new $\beta$-cell formation, has been demonstrated in rodent models following partial pancreatectomy, ${ }^{31}$ which was observed in our previous study as well. ${ }^{10}$ Here we observed PDX-1/CK19 double-positive ductal cells in geniposide-treated mice. In contrast, ductal PDX-1 expression was almost undetectable in vehicle-treated mice (4.6-fold and 4.7-fold higher in HFD and db/db mice than in vehicle-treated controls, respectively; Figure $5 \mathrm{~b}$ ). During $\beta$-cell regeneration, neurogenin 3 (Ngn3) is considered an important marker of the endocrine progenitors that contribute to $\beta$-cell neogenesis. ${ }^{32}$ The effect of geniposide on $\mathrm{Ngn} 3$ expression in ductal cells was measured (Figure 5b). Ngn3 is transiently expressed during endocrine differentiation. Here only 0.95 and $0.82 \%$ of ductal cells were $\mathrm{Ngn} 3+$ in geniposidetreated HFD and $\mathrm{db} / \mathrm{db}$ mice, respectively. However, Ngn3 expression was 10-fold higher in geniposide-treated mice than in vehicle-treated mice. Small islet-like cell clusters (ICCs) have been reported to originate as a result of the ductal

Figure 4 Geniposide normalized blood glucose levels and improved IPGTT in db/db mice and HFD mice. (a, b) Effects of geniposide on the fasting glucose levels and body weights in db/db mice and HFD mice. (c, d) Results of IPGTTand AUC. After 5- to 8-week geniposide treatment, IPGTT was performed after $12 \mathrm{~h}$ fast with $2 \mathrm{mg} / \mathrm{g} \mathrm{BW}$ of glucose in control, geniposide- or vehicle-treated mice. (e) Serum insulin levels of fasting HFD and db/db mice with/without geniposide treatment. $\left({ }^{\#} P<0.05\right.$ to WT or ND group; ${ }^{*} P<0.05$ to vehicle group). Data are shown as mean \pm S.E., $n=12$. (f) $\beta$-cell mass as product of pancreas mass and insulin-positive area divided by section area. Six consecutive sections from each pancreas (nine mice per group) were used for $\beta$-cell mass measurements. ( $P<0.05$ to WT or ND group; ${ }^{*} P<0.05$ to vehicle group) 
a
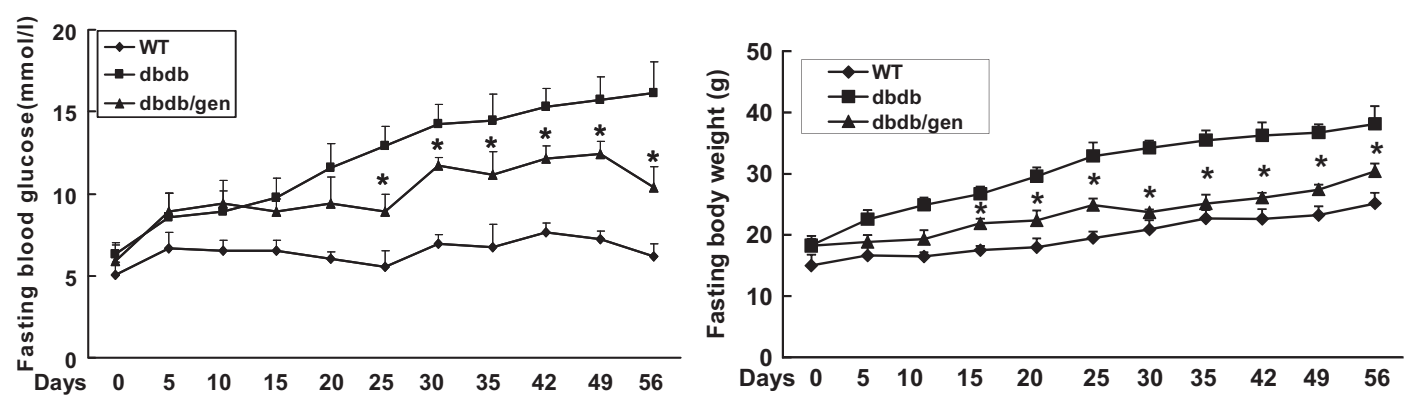

b
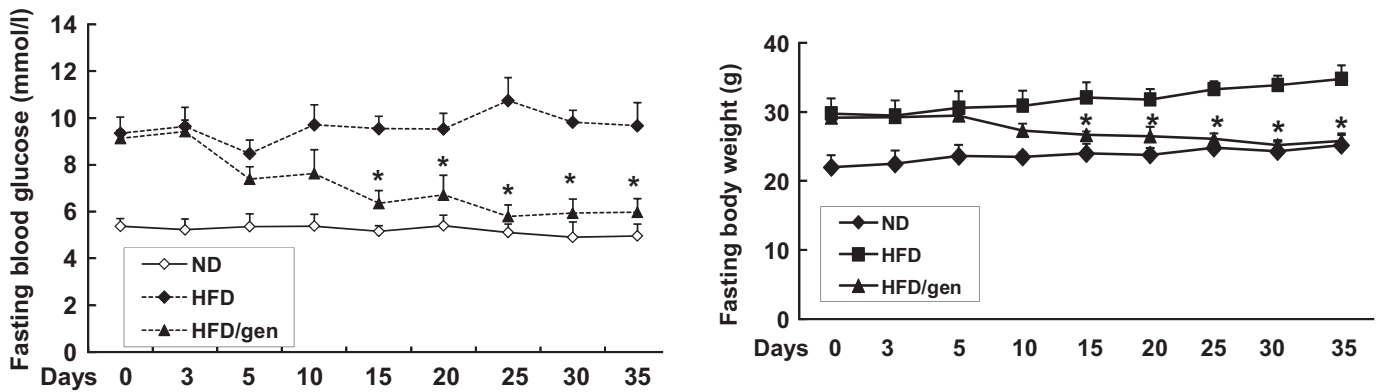

C
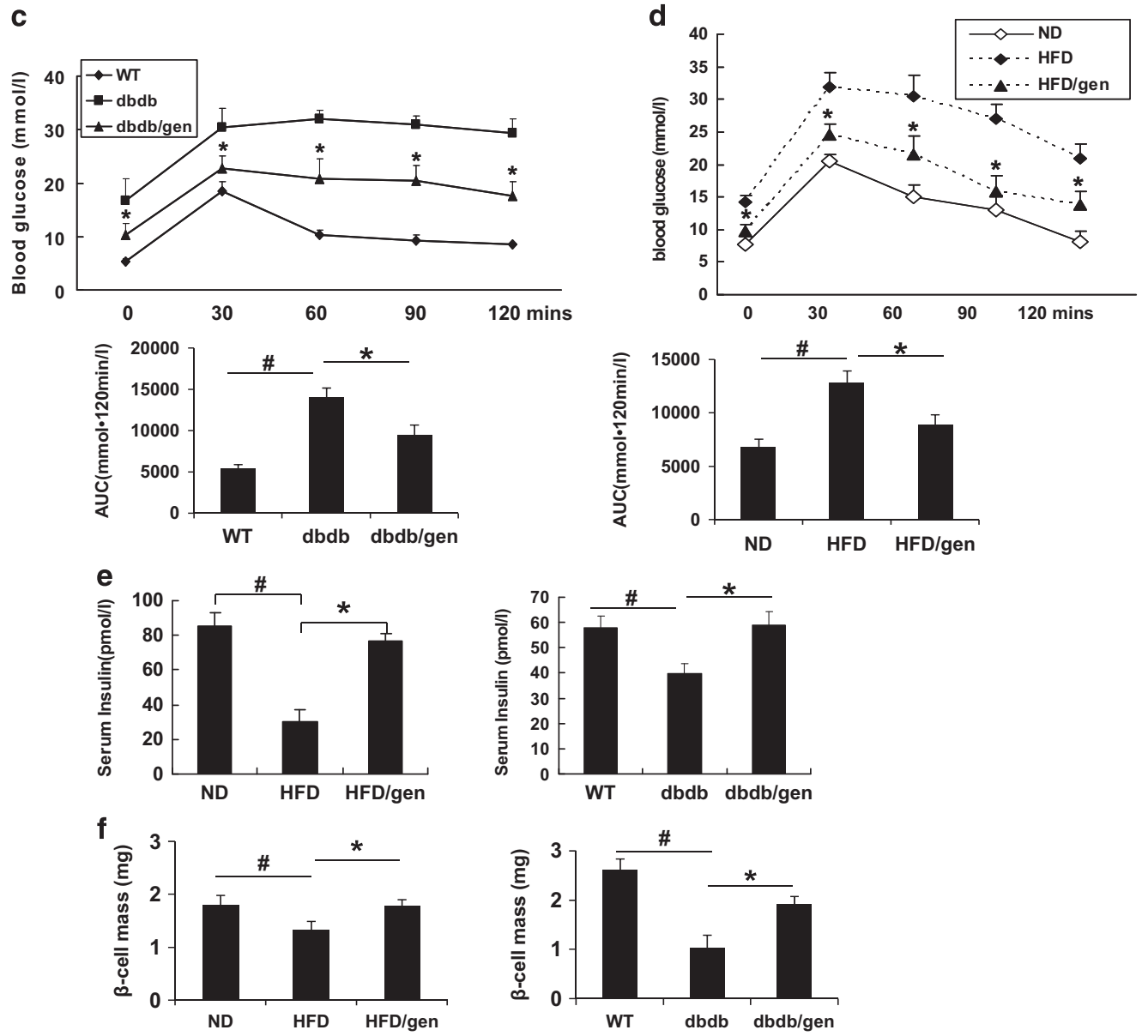
a

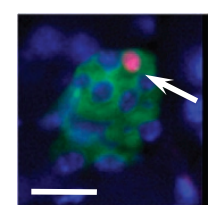

ND

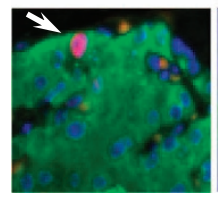

WT

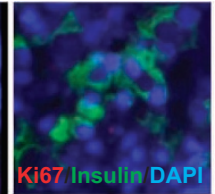

HFD

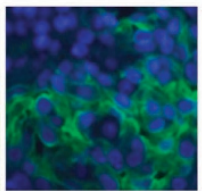

dbdb

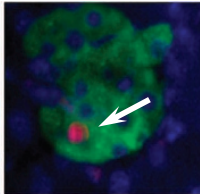

HFD/gen

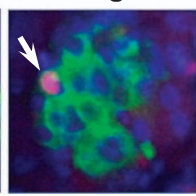

dbdb/gen

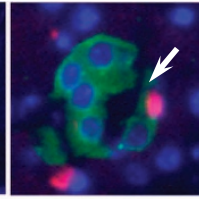

HFD/gen

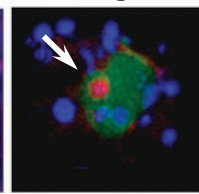

dbdb/gen
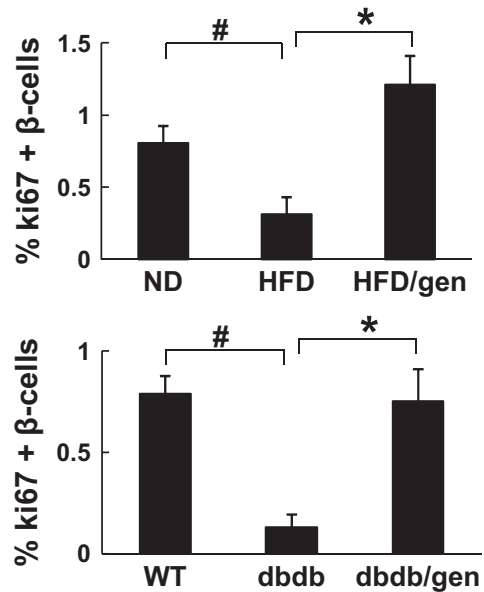

b

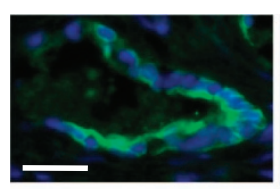

HFD

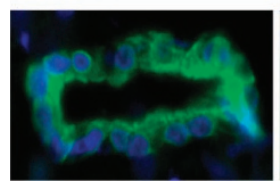

dbdb

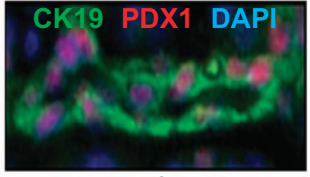

HFD/gen

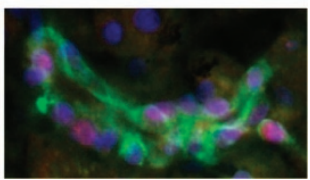

dbdb/gen

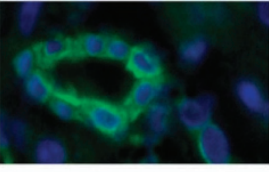

HFD

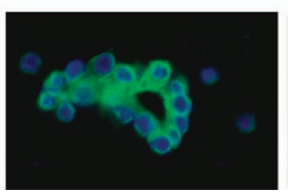

dbdb

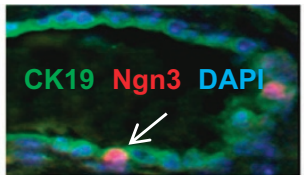

HFD/gen

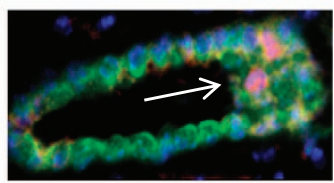

dbdb/gen
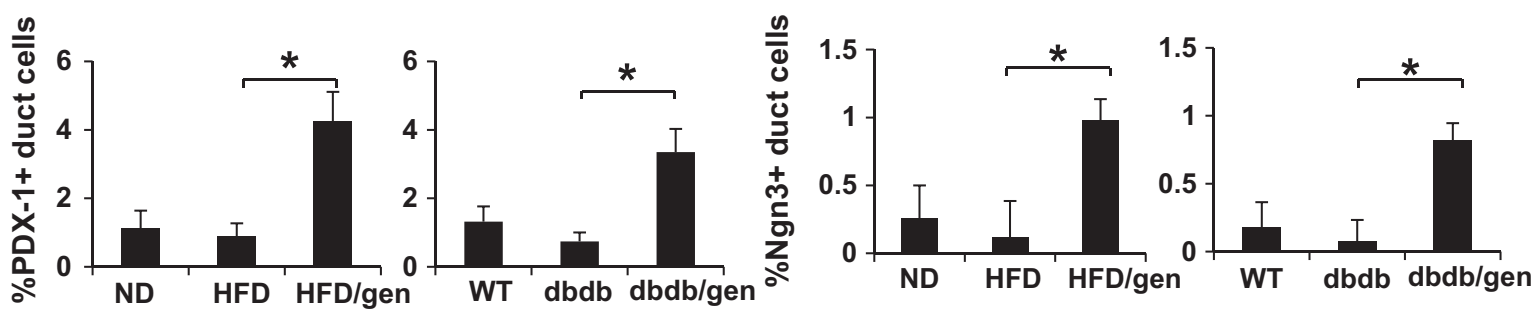

C

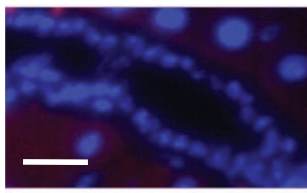

HFD

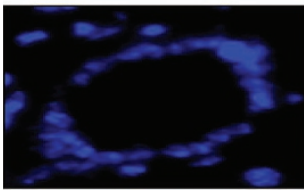

$d b d b$

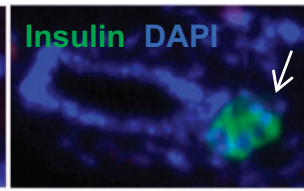

HFD/gen

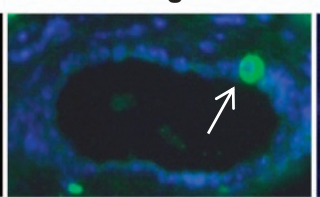

dbdb/gen

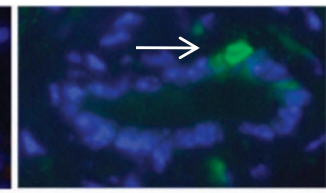

HFD/gen

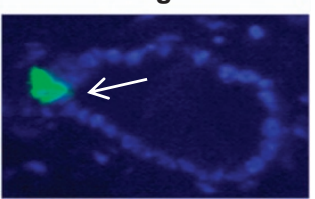

dbdb/gen

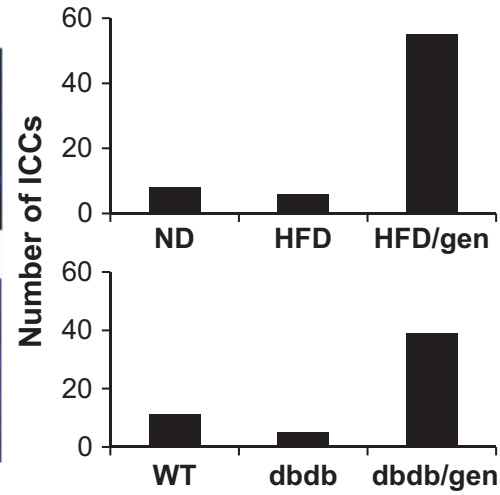

Figure 5 Geniposide promoted $\beta$-cell regeneration in vivo. (a) Proliferation of $\beta$-cell was measured in mice pancreatic sections by triple staining for Ki67 in red (indicated by white arrows), insulin in green, and DAPI in blue. (b) The PDX-1 and Ngn3 expressions in CK19-positive ductal epithelial cells. Representative images of ductal epithelial cells after triple staining for PDX-1 or Ngn3 in red, CK19 in green, and DAPI in blue were shown. (c) Small ICCs originated in the vicinity of the ducts. Representative pictures of ICCs were shown as insulin-positive staining (indicated by white arrows). Values are representative of four slides spanning the whole pancreas of each mouse and six mice per group. Data are shown as mean \pm S.E. ( ${ }^{\#} P<0.01$ vehicle to WT or ND group; ${ }^{*} P<0.01$ geniposide to vehicle group). Scale bars, $20 \mu \mathrm{m}$ 
epithelium differentiation. ${ }^{33}$ As presented in Figure $5 \mathrm{c}$, we also observed ICC structures next to ductal cells in geniposidetreated HFD and $\mathrm{db} / \mathrm{db}$ mice. The number of ICCs near the pancreatic ducts was counted (ND, 8; HFD, 6; HFD/gen, 55; and WT, 11; db/db, 5; db/db/gen, 39; Figure 5c). These data indicated that geniposide could promote $\beta$-cell regeneration in diabetic mice.

Geniposide stimulates ductal cell differentiation by upregulating TCF7L2 expression and activating the JAK2/STAT3 pathway. Along with the occurrence of Ki67positive $\beta$-cells and PDX-1, Ngn3-positive ductal epithelial cells in geniposide-treated diabetic mice, immunostaining results revealed that TCF7L2 expression (red; Figures $6 a$ and $b$ ) in $\beta$-cells and duct cells was significantly upregulated by geniposide treatment (Figures $6 a$ and $b$ ). These observations implied the importance of increased TCF7L2 expression in new $\beta$-cell formation.

To further confirm the effect of geniposide on ductal cell differentiation, geniposide-treated exocrine cells were embedded in paraffin and sections were analyzed by immunostaining for CK19, insulin, PDX-1, musculoaponeurotic fibrosarcoma oncogene family $A$ (MafA), and glucose transporter 2 (Glut2; Figure $6 \mathrm{c}$ ). MAF factors are considered to be essential for endocrine differentiation and MAFA acts as a transcriptional factor to cooperate synergistically with NEUROD1 and PDX-1. Glut2 is responsible for glucose uptake in $\beta$-cells and partially accounts for the glucose-sensing mechanism of $\beta$-cells. As shown in Figure $6 \mathrm{c}$, the cultured ductal cells formed islet-like clusters as we observed before. ${ }^{10}$ Consistent with the animal experiments, geniposide triggered the differentiation of cultured ductal cells in vitro by inducing expression of insulin and PDX-1. Similarly, other proteins expressed in pancreatic progenitors, including MafA and Glut2 were also detected in geniposide-treated ductal cells. A recent publication presented that TCF7L2 could positively regulate expressions of transcription factors like MAFA, PDX-1, and NKX6.1, ${ }^{34}$ further supporting the role of TCF7L2 in new $\beta$-cell formation as we observed here.

The signals that mediate ductal epithelial cell differentiation are largely unknown. The JAK2/STAT3 pathway has been shown to be involved in $\beta$-cell neogenesis from acinar cells. ${ }^{35}$ We previously demonstrated that TCF7L2 stimulated ductal cell differentiation through the JAK2/STAT3 pathway. ${ }^{10}$ In this study, mouse exocrine cells were exposed to AG490, a specific JAK2 inhibitor, or ICG001 to clarify whether geniposide-induced ductal epithelial cell differentiation is $\beta$-catenin/TCF7L2 or JAK2/STAT3 dependent. The western blotting results presented in Figure $6 \mathrm{~d}$ showed that geniposide treatment markedly stimulated TCF7L2 expression and JAK2/ STAT3 activation in exocrine cells, which was strongly inhibited by ICG001. Geniposide treatment induced insulin production within the ductal epithelial cell cluster, which was suppressed by ICG001 and AG490 (Figure 6e). The real-time (RT)-PCR results showed the geniposide treatment increased $P D X-1$ and insulin mRNA expression in cultured exocrine cells compared with their expression in DMSO-treated cells (Figure 6f). Treatment with ICG001 or AG490 significantly reduced $P D X-1$ and insulin mRNA expression in geniposidetreated exocrine cells.

\section{Discussion}

Loss of functional $\beta$-cells is the crucial event in the development of diabetes. ${ }^{36}$ The main goal for diabetes therapy is to prevent loss and dysfunction of existing $\beta$-cells, meanwhile, to promote new $\beta$-cell formation. Evidence obtained from both adult humans and animal models has shown that $\beta$-cell regeneration occurs in a variety of natural and experimental conditions. ${ }^{37-39}$ Unfortunately, adaptation of $\beta$-cell mass to insulin demand fails to achieve in T2DM. Novel agents designed to maintain $\beta$-cell numbers are urgently needed. A recent study reported that FTY720, a potent immunosuppressant isolated from the Chinese herb Iscaria sinclarii, is capable of promoting in vivo $\beta$-cell regeneration in $\mathrm{db} / \mathrm{db}$ mice. $^{27}$

Natural products are important resources for the antidiabetic drug development. ${ }^{40}$ For instance, metformin is derivative of plant products. ${ }^{41}$ However, the antidiabetic herbs and their bioactive extracts have not been intensively investigated so far. The effects of these compounds on $\beta$-cell survival and regeneration are still largely unknown.

Here we investigated, for the first time, whether geniposide may trigger new $\beta$-cell formation both in vitro and in vivo. In cultured mouse islets, geniposide protected $\beta$-cells from high glucose- or cytokine-induced apoptosis, and promoted $\beta$-cell proliferation. We demonstrated that geniposide activated $W n t / \beta$-catenin signaling via upregulating TCF7L2 expression. Importantly, geniposide could stimulate $\beta$-cell replication and induce ICC formation originated from the ductal epithelium both in HFD and $\mathrm{db} / \mathrm{db}$ mice, with a concomitant increase in TCF7L2 expression. Our findings revealed a novel role for geniposide in the promotion of $\beta$-cell survival and regeneration through activation of $\beta$-catenin/ TCF7L2 signaling. Interesting, a JBC paper reported that GLP-1 and Exendin 4-activated TCF7L2-dependent Wnt signaling to enhance $\beta$-cell proliferation, ${ }^{42}$ which provided additional evidence to imply a possible interaction between GLP-1R and Wnt signaling.

Currently, targets of antidiabetic drugs address several separate elements in the $\beta$-cell that potentially converge on TCF7L2 function. ${ }^{43}$ Direct or indirect stimulation of GLP-1 activity via treatment with DPP-4 inhibitors, GLP-1R agonists, or GPR119 agonists leads to activation of $\beta$-catenin via increased CAMP levels and improved TCF7L2-driven $\beta$-cell function. ${ }^{43}$ TCF7L2 could be appreciated as a new target for diabetes treatments. As we described before, ${ }^{9,11}$ TCF7L2 itself promoted $\beta$-cell proliferation, protected $\beta$-cell from apoptosis and improved insulin secretion in cultured islets. In line with our studies, other reports showed mouse islets treated with TCF7L2 siRNA displayed abnormal glucosestimulated insulin secretion. ${ }^{12}$ In TCF7L2 knockdown rats (generated with specific TCF7L2 morpholino-oligonucleotides), the process of $\beta$-cell regeneration was significantly inhibited. ${ }^{8}$ Selective deletion of TCF7L2 in mouse pancreas impairs insulin release and glucose homeostasis, indicating the direct role of this factor in controlling $\beta$-cell function. ${ }^{13}$ Our study implies a correlation between TCF7L2 expression and $\beta$-cell regeneration. TCF7L2 can trigger differentiation from ductal epithelial cells into $\beta$-cells in vitro. ${ }^{10}$ Similarly, Takamoto et al. ${ }^{14}$ reported that in mouse pancreatic $\beta$-cells, TCF7L2 has 
a

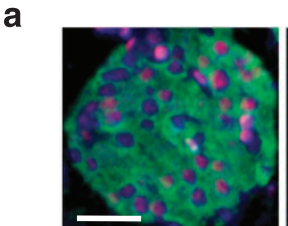

ND

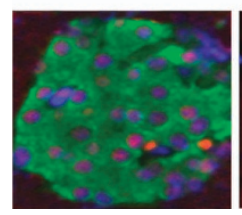

WT

b

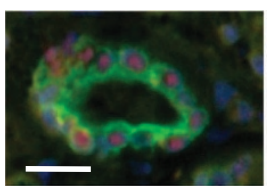

ND

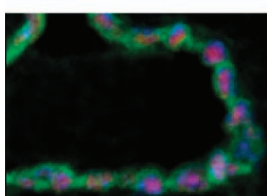

WT

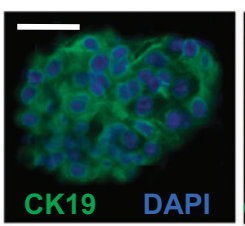

d

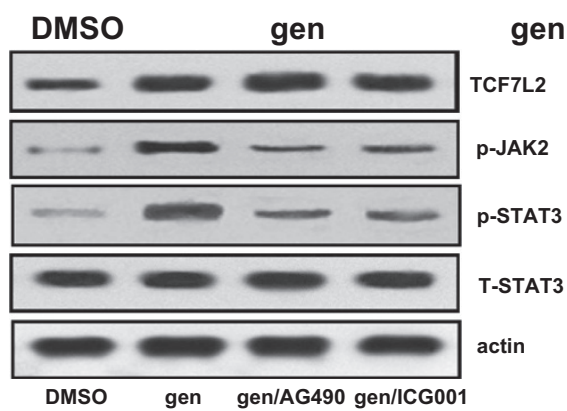

e

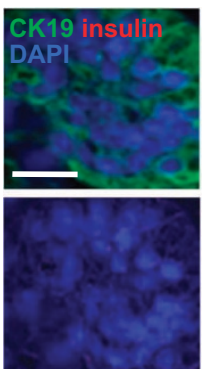

DMSO
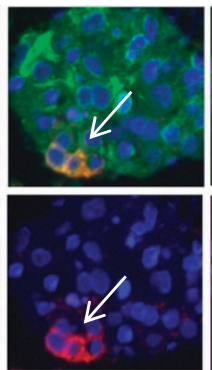

gen

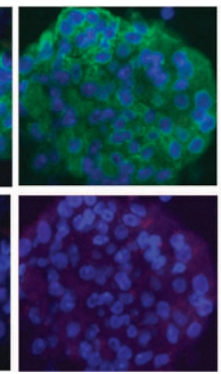

gen/AG490

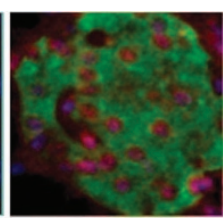

HFD/gen

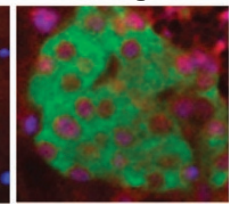

dbdb/gen

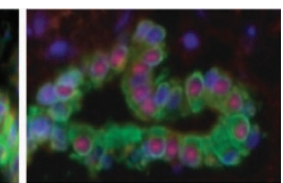

HFD/gen

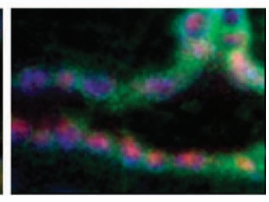

dbdb/gen
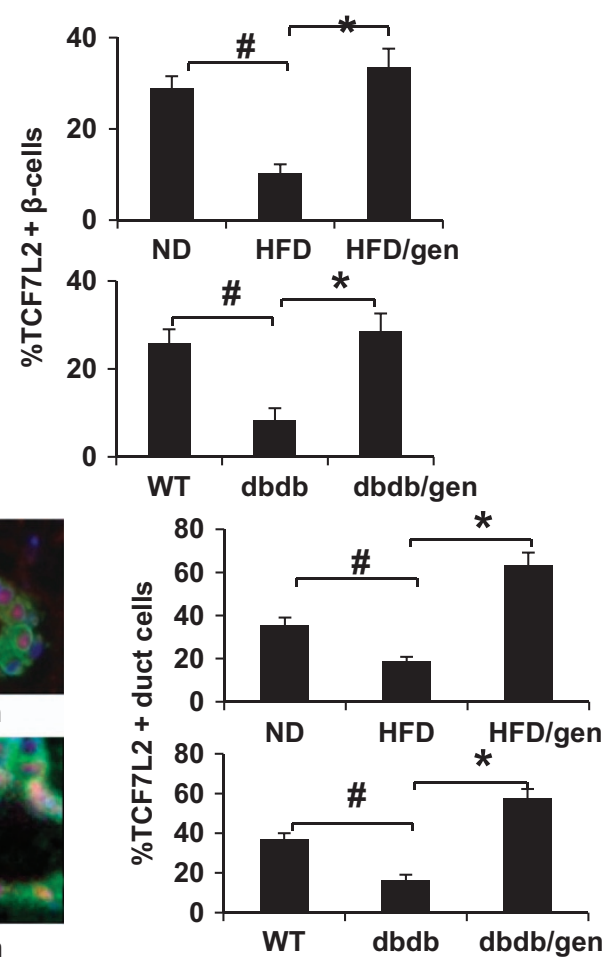

dbdb
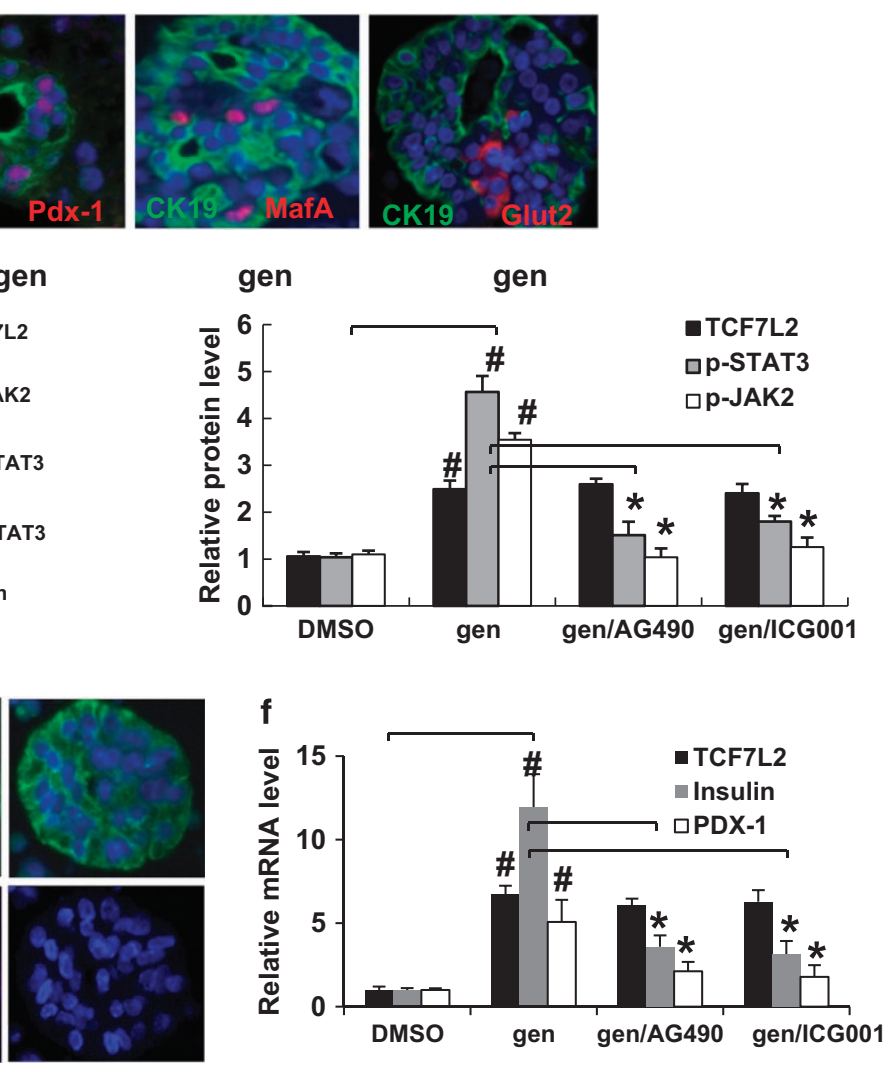

gen/ICG001 a crucial role in glucose homeostasis by regulating $\beta$-cell mass. DN-TCF7L2 mice (expressing a dominantnegative form of TCF7L2) showed impaired glucose tolerance and decreased insulin secretion. Marked reduction of the $\beta$-cell area and whole-pancreas insulin content were observed.

Notably, other reports have presented controversial results. ${ }^{44,45}$ Boj et al. $^{45}$ demonstrated that manipulation of 
Figure 6 Geniposide triggered ductal epithelial cell to $\beta$-cell conversion through upregulating TCF7L2 and activating JAK2/STAT3 pathway. TCF7L2 expression in islets $\beta$-cells (a) and in the ductal epithelium cells (b) were examined by triple staining of mice pancreatic sections for TCF7L2 in red, insulin, or CK19 in green, and DAPI in blue. Values are representative of three to four slides spanning the whole pancreas of each mouse and six mice per group. Data are shown as mean \pm S.E. $\left({ }^{\#} P<0.01\right.$ vehicle to WT or ND group; ${ }^{*} P<0.01$ geniposide to vehicle group). (c) Isolated mouse exocrine cells were cultured with $20 \mu \mathrm{M}$ geniposide for 4 days, then embedded in paraffin and sections were analyzed by immunostaining of CK19, insulin, PDX-1, MafA, and Glut2 to confirm the effect of geniposide on ductal cell differentiation. (d) Isolated mouse exocrine cells were cultured with different treatments (20 $\mu \mathrm{M}$ geniposide, $20 \mathrm{mM}$ AG490, and $25 \mu \mathrm{M} \mathrm{ICG001)} \mathrm{for} 4$ days. Upregulation of TCF7L2 and activation of JAK2/STAT3 were analyzed by western blot analysis. Data are shown from three independent experiments. (e) Effects of AG490 and ICG001 on the differentiation of ductal epithelial cells. The cells were examined by insulin (red, indicated by white arrows) and CK19 (green), and DAPI (blue) triple staining. (f) RT-PCR analyses of Pdx-1, insulin, and TCF7L2 expressions in treated ductal epithelial cells. The experiments were performed in triplicate. The levels of gene expressions were normalized to tubulin $(\# P<0.01$, geniposide to DMSO-treated group; ${ }^{*} P<0.01$, geniposide to AG490- or ICG001-treated group). Scale bars, $20 \mu \mathrm{m}$

islet TCF7L2 expression in adult mice had no significant effects on glucose-stimulated insulin secretion. The authors argued that TCF7L2-related disruption of $\beta$-cell function is probably an indirect consequence of primary events in liver and elsewhere. Thus, it is still far from a clear understanding of functions of TCF7L2 in metabolism. Novel approaches that address the evident complexity of these systems will be crucial for elucidating the biological functions of TCF7L2. ${ }^{46}$

The underlying mechanisms of $\beta$-cell regeneration are not fully understood so far. Growth factors have been shown to promote duct cell differentiation and $\beta$-cell neogenesis. Epidermal growth factor in combination with gastrin, ${ }^{47}$ insulin-like growth factor, transforming growth factor- $\beta,{ }^{35,48}$ and islet neogenesis-associated protein ${ }^{49}$ have been demonstrated to stimulate $\beta$-cell growth. The $\mathrm{Wnt} / \beta$-catenin signaling has a crucial role in embryonic development and cell regeneration, differentiation, proliferation, and apoptosis. The JAK2/STAT3 pathway is an important signaling pathway during $\beta$-cell generation, ${ }^{35}$ and STAT-Wnt interactions were reported before in other cells. ${ }^{50,51}$ A functional TCF-binding element was detected in the STAT3 promoter, which specifically bound to TCF7L2. ${ }^{51}$ As we described previously, TCF7L2 can trigger differentiation of ductal epithelial cells into $\beta$-cells in vitro by activating the JAK2/STAT3 pathway. ${ }^{10}$ Here we identified that the upregulation of TCF7L2 expression by geniposide in vitro could lead to JAK2/STAT3 activation and duct cell differentiation consequently, which further confirmed the involvement of STAT-Wnt interactions in cell differentiation.

On the basis of the crosstalk between GLP-1R signaling and TCF7L2, we used exendin (9-39), and ICG001 to clarify the role of GLP-1R and Wnt signaling in geniposide activity. Interestingly, the regulatory effects of geniposide on p-AKT, p-GSK3 $\beta$, and c-casp3 were strongly blocked by ICG001, whereas exen (9-39) only exhibited mild suppressive effects. Similarly, the protecting effect of geniposide on $\beta$-cell survival was prevented by ICG001. Moreover, $\beta$-cell survival could not be preserved by geniposide in the case of $\beta$-catenin knocked down by si $\beta$-catenin. Here we noticed that geniposide could enhance the GLP-1R expression. We hypothesize that geniposide could counteract the negative effects of exendin (9-39) by upregulating TCF7L2 and GLP-1R, which can enhance the activation of GLP-1R downstream pathway.

Collectively, we propose a novel mechanism for the effects of geniposide on $\beta$-cell regeneration and survival. In this model, $\beta$-catenin/TCF7L2 is the core component required for the functions of geniposide. Geniposide activates $\beta$-catenin/ TCF7L2 transcription complex, which could lead to $\beta$-cell regeneration via stimulating $\beta$-cell proliferation and differentiation. Meanwhile, geniposide promoted $\beta$-cell survival by inhibiting c-casp3 level to suppress $\beta$-cell apoptosis. Our data support $\beta$-catenin/TCF7L2 as a possible target for diabetes treatment to promote new $\beta$-cell formation.

The latest report published in August 2014 by a group at Lund University stated new information that TCF7L2 could positively regulate expressions of transcription factors like MAFA, PDX-1, and NKX6.1, which are crucial for $\beta$-cell neogenesis, through targeting on insulin gene enhancerbinding protein-1 (ISL1). ${ }^{34}$ This finding provides additional evidence to imply the role of TCF7L2 in $\beta$-cell regeneration. The association between geniposide and ISL1 needs to be further investigated in our future studies.

\section{Materials and Methods}

Reagent. Geniposide (purity $>98 \%$ ) was purchased from the National Institute for the Control of Pharmaceutical and Biological Products (Beijing, China). AG490, Exendin (9-39) were from Sigma (St. Louis, MO, USA), and ICG001 was from Selleckchem (Houston, TX, USA).

Animals. All animal experiments were conducted in accordance with Provisions and General Recommendation of Chinese Experimental Animals Administration Legislation and approved by the Research Animal Care Committee of Nanjing Medical University. The animals were housed in a temperature-controlled room with a 12-h light/dark cycle and were allowed free access to food and water in the course of experiments. Four-week-month old male C57BL/6J mice (SLAC Laboratory Animals, Shanghai, China) were fed with a HFD (60 kcal\% fat, D12492, Research Diets, New Brunswick, NJ, USA) ${ }^{10}$ or normal chow diet. Geniposide intervention (100 mg/kg) was initiated after 12 weeks of the HFD. Four-week old male C57BI/KsJ (BKS) mice and BKS.Cg-Dock $7^{\mathrm{m}}+/+\mathrm{Lepr}^{\mathrm{db}} / \mathrm{JNju}(\mathrm{db} / \mathrm{db})$ mice were ordered from Model Animal Research Center of Nanjing University. Geniposide solution was prepared in $0.9 \% \mathrm{NaCl}$ and delivered by oral gavage at dosage of $100 \mathrm{mg} / \mathrm{kg}$ daily. The control group was given vehicle. Geniposide or vehicle was given for additional $35-56$ days. A total of 12 mice in each group were used.

Intraperitoneal glucose tolerance tests (IPGTTs). For IPGTTs, mice were fasted $12 \mathrm{~h}$ overnight and injected intraperitoneally with glucose at a dose of $2 \mathrm{mg} / \mathrm{g}$ body weight. Blood samples were obtained at time points $0,30,60,90$, and $120 \mathrm{~min}$ for glucose measurements using a Glucometer (Accu-Chek Active; Roche, Indianapolis, IN, USA). Insulin was determined using a mouse insulin ELISA kit (Alpco, Windham, NH, USA).

Analysis of $\boldsymbol{\beta}$-cell mass. $\beta$-cell mass was measured as previously described. ${ }^{10}$ In brief, pancreatic sections (spanning the width of the pancreas, which was cut along the head-tail axis) were stained with anti-mouse insulin antibody (ab7842, Abcam, Cambridge, MA, USA) and scanned by a Nikon MEA53200 (Nikon, Tokyo, Japan) microscope. The cross-sectional areas of pancreas and $\beta$-cells were determined by NIS-Elements software (Nikon). $\beta$-cell mass/pancreas was estimated by the product of the relative cross-sectional area of $\beta$-cells per total tissue and the weight of the pancreas. 
Mouse pancreatic islets, exocrine cell isolation and culture. Mouse islets were isolated from C57BL/6J mice (SLAC Laboratory Animals) by common bile duct perfusion using Collagenase type 4 (Worthington, Lakewood, NJ, USA) as described previously ${ }^{11}$ and cultured in RPMl 1640 containing $11.1 \mathrm{mmo} / /$ glucose, $100 \mathrm{U} / \mathrm{ml}$ penicillin, $100 \mathrm{mg} / \mathrm{ml}$ streptomycin, and 10\% FCS (Invitrogen, Carlsbad, CA, USA). Isolated pancreatic exocrine cells from islet isolation were cultured in DMEM supplemented with 10\% FCS and penicillin-streptomycin (1\%).

Min6 cell culture. Min6 cells were obtained from ATCC (American Type Culture Collection, Manassas, VA, USA) and maintained in $5 \mathrm{mM}$ glucose DMEM, supplemented with 10\% FBS (Invitrogen), $50 \mathrm{mmol} / \mathrm{b}$ b-mercaptoethanol, $100 \mathrm{U} / \mathrm{ml}$ penicillin, and $0.1 \mathrm{mg} / \mathrm{ml}$ streptomycin in $5 \% \mathrm{CO}_{2}$ at $37^{\circ} \mathrm{C}$.

Treatments of diabetic stimuli. For treatment of islets or Min6 cells with diabetic stimuli, the culture medium contained $33.3 \mathrm{mM}$ glucose or $2 \mathrm{ng} / \mathrm{ml}$ recombinant IL-1 $\beta$ plus $1000 \mathrm{U} / \mathrm{ml}$ recombinant IFN- $\gamma$ (ILIF; R\&D Systems) with geniposide $(20 \mu \mathrm{M})$ for 3 days, cells treated with DMSO served as a control.

RNA interference transfection. The small interfering RNA transfection experiment was performed by using lipofectamine 2000 reagent (Liptofectamine2000; Invitrogen) according to the manufacturer's instructions. Islets were transfected with $100 \mathrm{nmol} / \mathrm{l}$ siRNA against $\beta$-catenin (sc-29210, Santa Cruz, Dallas, TX, USA) or scramble siRNA (sc-37007, Santa Cruz). After transfection for $24 \mathrm{~h}$, the medium was aspirated and replaced by fresh culture medium with/without geniposide for the next 3-day culture.

Immunofluorescence staining. Pancreatic tissue and cultured mouse islets were processed as previously described. ${ }^{9}$ Details of antibodies used and the staining procedures were provided in the supplemental files.

RNA extraction and RT-PCR. Total RNA was isolated from cultured mouse pancreatic islets or exocrine cells as described previously. ${ }^{10}$ For quantitative analysis, Applied Biosystems StepOne Real-Time PCR system (Applied Biosystems, Carlsbad, CA, USA) with a commercial kit (Power SYBR Green PCR Master Mix; Applied Biosystems) was used. Primers used were provided in Supplementary Files.

Nuclear fractionation. Nuclear and cytoplasm extractions of Min6 cells were performed according to the instructions of NE-PER Nuclear and Cytoplasm Extraction Reagents (Pierce Biotechnology, Rockford, IL, USA). The purity of fractions was analyzed by probing the membranes with anti-GAPDH for cytosolic and anti-PARP for nuclear extracts.

Western blot analysis. Cultured islets or Min6 cells were washed in PBS and lysed. PVDF membranes were incubated with anti-TCF7L2 (\#2565), anti-actin (\#4967), anti-p-AKT (Serine473, \#9271), anti-AKT (\#9272), anti-p-GSK3 $\beta$ (Ser9 \#9336), anti-PARP (\#9542), anti-GAPDH (\#2118), anti-c-casp3 (\#9661), anti-stat3 (\#9132), anti-p-stat3 (Tyr705, \#9131), anti-PKA C- $\alpha$ ( \#5842; all from Cell Signaling, Danvers, MA, USA), anti- $\beta$-catenin (ab6302), anti-GLP-1R (ab39072), anti-p-Jak2 (ab68268; all from Abcam), followed by incubation with horseradishperoxidase-linked IgG peroxidase. The bands were visualized and densities of the bands were analyzed using Tanon Chemlmaging Systems (Nanjing, China).

Statistical analysis. Data are presented as means \pm S.D. and were analyzed by paired Student's $t$-test or by analysis of variance with a Bonferroni correction for multiple group comparisons.

\section{Conflict of Interest}

The authors declare no conflict of interest.

Acknowledgements. This work was supported by EFSD/CDS/Lilly Program for Collaborative Research between China and Europe, the Natural Science Foundation of China (Grant No. 81102488, 81370924, 31071250, and 81473293), the Natural Science Foundation of Jiangsu Province (Grant No. BK2011865), and the Foundation of Jiangsu Province Administration of Traditional Chinese Medicine (Grant No. LZ13066). We thank Professor Kathrin Maedler (University of Bremen) for excellent assistance in discussion of the paper.
1. Robertson RP. Type II diabetes, glucose "non-sense," and islet desensitization. Diabetes 1989; 38: 1501-1505.

2. Prentki M, Nolan CJ. Islet beta cell failure in type 2 diabetes. J Clin Invest 2006; 116 : 1802-1812.

3. Dor Y, Brown J, Martinez OI, Melton DA. Adult pancreatic beta-cells are formed by selfduplication rather than stem-cell differentiation. Nature 2004; 429: 41-46.

4. Bonner-Weir S, Weir GC. New sources of pancreatic beta-cells. Nat Biotechnol 2005; 23: $857-861$.

5. Welters HJ, Kulkarni RN. Wnt signaling: relevance to beta-cell biology and diabetes. Trends Endocrinol Metab 2008; 19: 349-355.

6. Jin T, Liu L. The Wnt signaling pathway effector TCF7L2 and type 2 diabetes mellitus. Mol Endocrinol 2008; 22: 2383-2392.

7. Rulifson IC, Karnik SK, Heiser PW, ten Berge D, Chen H, Gu X et al. Wnt signaling regulates pancreatic beta cell proliferation. Proc Natl Acad Sci USA 2007; 104: 6247-6252.

8. Figeac F, Uzan B, Faro M, Chelali N, Portha B, Movassat J. Neonatal growth and regeneration of beta-cells are regulated by the Wnt/beta-catenin signaling in normal and diabetic rats. Am J Physiol Endocrinol Metab 2010; 298: E245-E256.

9. Shu L, Matveyenko AV, Kerr-Conte J, Cho JH, Mclntosh CH, Maedler K. Decreased TCF7L2 protein levels in type 2 diabetes mellitus correlate with downregulation of GIP- and GLP-1 receptors and impaired beta-cell function. Hum Mol Genet 2009; 18: 2388-2399.

10. Shu L, Zien K, Gutjahr G, Oberholzer J, Pattou F, Kerr-Conte J et al. TCF7L2 promotes beta cell regeneration in human and mouse pancreas. Diabetologia 2012; 55: 3296-3307.

11. Shu L, Sauter NS, Schulthess FT, Matveyenko AV, Oberholzer J, Maedler K. Transcription factor 7 -like 2 regulates beta-cell survival and function in human pancreatic islets. Diabetes 2008; 57: 645-653.

12. da Silva Xavier G, Loder MK, McDonald A, Tarasov Al, Carzaniga R, Kronenberger $\mathrm{K}$ et al. TCF7L2 regulates late events in insulin secretion from pancreatic islet beta-cells. Diabetes 2009; 58: 894-905.

13. da Silva Xavier G, Mondragon A, Sun G, Chen L, McGinty JA, French PM et al. Abnormal glucose tolerance and insulin secretion in pancreas-specific Tcf7l2-null mice. Diabetologia 2012; 55: 2667-2676.

14. Takamoto I, Kubota N, Nakaya K, Kumagai K, Hashimoto S, Kubota T et al. TCF7L2 in mouse pancreatic beta cells plays a crucial role in glucose homeostasis by regulating beta cell mass. Diabetologia 2014; 57: 542-553.

15. Yi F, Brubaker PL, Jin T. TCF-4 mediates cell type-specific regulation of proglucagon gene expression by beta-catenin and glycogen synthase kinase-3beta. J Biol Chem 2005; 280: 1457-1464.

16. Koo HJ, Song YS, Kim HJ, Lee YH, Hong SM, Kim SJ et al. Antiinflammatory effects of genipin, an active principle of gardenia. Eur J Pharmacol 2004; 495: 201-208.

17. Pham TQ, Cormier F, Farnworth E, Tong VH, Van Calsteren MR. Antioxidant properties of crocin from Gardenia jasminoides Ellis and study of the reactions of crocin with linoleic acid and crocin with oxygen. J Agric Food Chem 2000; 48: 1455-1461.

18. Kimura $\mathrm{Y}$, Okuda H, Arichi S. Effects of geniposide isolated from Gardenia jasminoides on metabolic alterations in high sugar diet-fed rats. Chem Pharm Bull (Tokyo) 1982; 30: 4444-4447.

19. Wu SY, Wang GF, Liu ZQ, Rao JJ, Lu L, Xu W et al. Effect of geniposide, a hypoglycemic glucoside, on hepatic regulating enzymes in diabetic mice induced by a high-fat diet and streptozotocin. Acta Pharmacol Sin 2009; 30: 202-208.

20. Guo LX, Xia ZN, Gao X, Yin F, Liu JH. Glucagon-like peptide 1 receptor plays a critical role in geniposide-regulated insulin secretion in INS-1 cells. Acta Pharmacol Sin 2012; 33: 237-241.

21. Liu J, Yin F, Xiao H, Guo L, Gao X. Glucagon-like peptide 1 receptor plays an essential role in geniposide attenuating lipotoxicity-induced beta-cell apoptosis. Toxicol In Vitro 2012; 26: 1093-1097.

22. Donath MY, Ehses JA, Maedler K, Schumann DM, Ellingsgaard H, Eppler E et al. Mechanisms of beta-cell death in type 2 diabetes. Diabetes 2005; 54(Suppl 2): S108-S113.

23. Maedler K, Sergeev P, Ris F, Oberholzer J, Joller-Jemelka HI, Spinas GA et al. Glucoseinduced beta-cell production of interleukin-1beta contributes to glucotoxicity in human pancreatic islets. J Clin Invest 2002; 110: 851-860.

24. Koole C, Pabreja K, Savage EE, Wootten D, Furness SG, Miller LJ et al. Recent advances in understanding GLP-1R (glucagon-like peptide-1 receptor) function. Biochem Soc Trans 2013; 41: 172-179.

25. Xu G, Kaneto H, Laybutt DR, Duvivier-Kali VF, Trivedi N, Suzuma K et al. Downregulation of GLP-1 and GIP receptor expression by hyperglycemia: possible contribution to impaired incretin effects in diabetes. Diabetes 2007; 56: 1551-1558.

26. Zhou J, Livak MF, Bernier M, Muller DC, Carlson OD, Elahi D et al. Ubiquitination is involved in glucose-mediated downregulation of GIP receptors in islets. Am J Physiol Endocrinol Metab 2007; 293: E538-E547.

27. Zhao Z, Choi J, Zhao C, Ma ZA. FTY720 normalizes hyperglycemia by stimulating beta-cell in vivo regeneration in $\mathrm{db} / \mathrm{db}$ mice through regulation of cyclin D3 and p57(KIP2). J Biol Chem 2012; 287: 5562-5573.

28. Han SJ, Choi SE, Yi SA, Lee SJ, Kim HJ, Kim DJ et al. $\quad \beta$-Cell-protective effect of 2aminobicyclo-(2,2,1)-heptane-2-carboxylic acid as a glutamate dehydrogenase activator in $\mathrm{db} / \mathrm{db}$ mice. J Endocrinol 2012; 212: 307-315. 
29. Do GM, Jung UJ, Park HJ, Kwon EY, Jeon SM, McGregor RA et al. Resveratrol ameliorates diabetes-related metabolic changes via activation of AMP-activated protein kinase and its downstream targets in db/db mice. Mol Nutr Food Res 2012; 56: 1282-1291.

30. Hao E, Tyrberg B, Itkin-Ansari P, Lakey JR, Geron I, Monosov EZ et al. Beta-cell differentiation from nonendocrine epithelial cells of the adult human pancreas. Nat Med 2006 12: $310-316$.

31. Uzan B, Figeac F, Portha B, Movassat J. Mechanisms of KGF mediated signaling in pancreatic duct cell proliferation and differentiation. PLoS One 2009; 4: e4734.

32. Gradwohl G, Dierich A, LeMeur M, Guillemot F. neurogenin3 is required for the development of the four endocrine cell lineages of the pancreas. Proc Natl Acad Sci USA 2000; 97: $1607-1611$.

33. Lee JH, Jo J, Hardikar AA, Periwal V, Rane SG. Cdk4 regulates recruitment of quiescent beta-cells and ductal epithelial progenitors to reconstitute beta-cell mass. PLoS One 2010; 5 : e8653

34. Zhou Y, Park SY, Su J, Bailey K, Ottosson-Laakso E, Shcherbina L et al. TCF7L2 is a master regulator of insulin production and processing. Hum Mol Genet 2014; 23 : 6419-6431.

35. Baeyens L, Bonne S, German MS, Ravassard P, Heimberg H, Bouwens L. Ngn3 expression during postnatal in vitro beta cell neogenesis induced by the JAK/STAT pathway. Cell Death Differ 2006; 13: 1892-1899.

36. Butler AE, Janson J, Bonner-Weir S, Ritzel R, Rizza RA, Butler PC. Beta-cell deficit and increased beta-cell apoptosis in humans with type 2 diabetes. Diabetes 2003; 52: 102-110.

37. Bonner-Weir S, Li WC, Ouziel-Yahalom L, Guo L, Weir GC, Sharma A. Beta-cell growth and regeneration: replication is only part of the story. Diabetes 2010; 59: 2340-2348.

38. Gianani R. Beta cell regeneration in human pancreas. Semin Immunopathol 2011; 33: 23-27.

39. Desgraz R, Bonal C, Herrera PL. $\beta$-cell regeneration: the pancreatic intrinsic faculty. Trends Endocrinol Metab 2011; 22: 34-43.

40. Newman DJ, Cragg GM. Natural products as sources of new drugs over the last 25 years. J Nat Prod 2007; 70: 461-477.

41. Marles R, Durst T, Kobaisy M, Soucy-Breau C, Abou-Zaid M, Arnason JT et al. Pharmacokinetics, metabolism and toxicity of the plant-derived photoxin alpha-terthienyl. Pharmacol Toxicol 1995; 77: 164-168.

42. Liu Z, Habener JF. Glucagon-like peptide-1 activation of TCF7L2-dependent Wnt signaling enhances pancreatic beta cell proliferation. J Biol Chem 2008; 283: 8723-8735

43. Hughes TE. Emerging therapies for metabolic diseases-the focus is on diabetes and obesity. Curr Opin Chem Biol 2009; 13: 332-337.
44. Lyssenko V, Lupi R, Marchetti P, Del Guerra S, Orho-Melander M, Almgren P et al. Mechanisms by which common variants in the TCF7L2 gene increase risk of type 2 diabetes. J Clin Invest 2007; 117: 2155-2163.

45. Boj SF, van Es JH, Huch M, Li VS, Jose A, Hatzis $P$ et al. Diabetes risk gene and Wnt effector Tcf7l2/TCF4 controls hepatic response to perinatal and adult metabolic demand. Cell 2012; 151: 1595-1607.

46. McCarthy MI, Rorsman P, Gloyn AL. TCF7L2 and diabetes: a tale of two tissues, and of two species. Cell Metab 2013; 17: 157-159.

47. Suarez-Pinzon WL, Lakey JR, Brand SJ, Rabinovitch A. Combination therapy with epidermal growth factor and gastrin induces neogenesis of human islet \{beta\}-cells from pancreatic duct cells and an increase in functional \{beta\}-cell mass. J Clin Endocrinol Metab 2005; 90: 3401-3409.

48. Shin JA, Hong OK, Lee HJ, Jeon SY, Kim JW, Lee SH et al. Transforming growth factor-beta induces epithelial to mesenchymal transition and suppresses the proliferation and transdifferentiation of cultured human pancreatic duct cells. J Cell Biochem 2011; 112: 179-188.

49. Rafaeloff R, Pittenger GL, Barlow SW, Qin XF, Yan B, Rosenberg L et al. Cloning and sequencing of the pancreatic islet neogenesis associated protein (INGAP) gene and its expression in islet neogenesis in hamsters. J Clin Invest 1997; 99: 2100-2109.

50. Liu YC, Lai WC, Chuang KA, Shen YJ, Hu WS, Ho CH et al. Blockade of JAK2 activity suppressed accumulation of beta-catenin in leukemic cells. J Cell Biochem 2010; 111: 402-411.

51. Yan S, Zhou C, Zhang W, Zhang G, Zhao X, Yang S et al. beta-Catenin/TCF pathway upregulates STAT3 expression in human esophageal squamous cell carcinoma. Cancer Lett 2008; 271: 85-97.

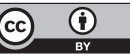

Cell Death and Disease is an open-access journal published by Nature Publishing Group. This work is licensed under a Creative Commons Attribution 4.0 International License. The images or other third party material in this article are included in the article's Creative Commons license, unless indicated otherwise in the credit line; if the material is not included under the Creative Commons license, users will need to obtain permission from the license holder to reproduce the material. To view a copy of this license, visit http://creativecommons.org/licenses/by/4.0/ 